\title{
Inverse Relationship between Galactokinase Activity and 2-Deoxygalactose Resistance in Chinese Hamster Ovary Cells
}

\author{
Carolyn D. Whitfield, ${ }^{1}$ Bruce Buchsbaum, ${ }^{2}$ Richard Bostedor, ${ }^{1}$ \\ and Ernest H. Y. Chu'
}

Departments of Biological Chemistry and Human Genetics, ${ }^{2}$ University of Michigan, Ann Arbor, Michigan 48109

Received May 22, 1978-Final July 24, 1978

\begin{abstract}
Galactokinase activity is reduced in 12 independent clones of Chinese hamster ovary cells resistant to 2-deoxygalactose. The frequency of resistant colonies is increased with chemical mutagens. The resistant phenotype is stable in the absence of selection. There is an inverse correlation between the levels of galactokinase activity and the cloning efficiency in deoxygalactose. Cells with high resistance have $1 \%$ or less of the enzyme activity observed in the parental cells; while cells with low resistance have 10-30\% galactokinase activity. Studies with tetraploid hybrid cells reveal that resistance to deoxygalactose is a recessive trait and that cells with high resistance do not complement those with low resistance. In cell lines with low resistance, the $\mathrm{K}_{m}$ for galactose, $\mathrm{K}_{i}$ for deoxygalactose, $\mathrm{K}_{m}$ for ATP, and thermolability were not significantly altered compared to sensitive parental cells. Although the possibility of mutation at the structural gene locus has not been ruled out, the reduced enzyme activity may also be due to mutation at a regulatory site which affects the number of galactokinase molecules per cell.
\end{abstract}

\section{INTRODUCTION}

Chinese hamster ovary (CHO) cells which are resistant to 2deoxygalactose (DGA) have been isolated in order to obtain cells with a defect in galactose transport or metabolism (Leloir pathway). 
Galactose $\underset{\text { kinase }^{3}}{\stackrel{\text { ATP }}{\longrightarrow}}$ Galactose-1-P $\underset{\text { transferase }}{\stackrel{\text { UDPG }}{\rightleftharpoons}}$ UDP-Gal ${ }^{1} \underset{\text { epimerase }}{\rightleftharpoons}$ UDPG

Growth of $\mathrm{CHO} \mathrm{K} 1$ is inhibited by the galactose analog 2-deoxygalactose in the presence of glucose. This inhibition is reversed by galactose, indicating that the action of the analog is specific for galactose-metabolizing enzymes.

Alper and Ames (1) have used DGA to select for mutants in Salmonella typhimurium which are deleted for galactokinase, UDPG epimerase, and galactose-1-phosphate uridylyltransferase. DGA has also been used to select for galactose permease mutants in S. typhimurium (2). While this work was in progress, Thirion et al. (3) reported using DGA to isolate Chinese hamster lung cells with a defect in galactokinase. In this paper, we describe the isolation, and genetic and biochemical characterization of deoxygalactose-resistant cells $\left(\mathrm{Dga}^{\mathrm{R}}\right)$ from $\mathrm{CHO}$ K1. All resistant clones have reduced levels of galactokinase, which also catalyzes the ATP phosphorylation of deoxygalactose to deoxygalactose1-phosphate (DGA-1-P) (3). A preliminary report of this work has appeared (4).

\section{MATERIALS AND METHODS}

Cell Lines and Cell Culture. Cells were grown in modified Eagle's minimum essential medium (5) (Gibco or K.C.) containing Earle's salts, hypoxanthine $(\mathrm{H}), 37 \mu \mathrm{M}$; thymidine $(\mathrm{T}), 21 \mu \mathrm{M}$; uridine (U), $21 \mu \mathrm{M} ; 1$ $\mathrm{mM}$ pyruvate; 1.5 times the normal levels of vitamins and essential amino acids; and 2 times nonessential amino acids, with $5 \%$ fetal calf serum (Gibco or K.C.) for monolayer growth and $10 \%$ serum for suspension culture. For cell culture $17.9 \mathrm{mM} \mathrm{NaHCO}_{3}$ and $8.3 \mathrm{mM} \mathrm{NaCl}$ were added to the growth media; for plating experiments, $11.9 \mathrm{mM} \mathrm{NaHCO}_{3}$ and 14.3 $\mathrm{mM} \mathrm{NaCl}$ were added. Serum dialyzed by ultrafiltration with an Amicon UM 10 filter was used in medium lacking proline, medium containing 6thioguanine, or in medium where $14 \mathrm{mM}$ galactose was substituted for glucose. HAT medium contained $3.2 \mu \mathrm{M}$ aminopterin (A), hypoxanthine and thymidine as above. Cells were grown at $37^{\circ} \mathrm{C}$ in a humid atmosphere of $5 \% \mathrm{CO}_{2}$ in air.

CHO K1 (American Type Culture Collection), which is auxotrophic for proline ( Pro $^{-} \mathrm{Gat}^{+} \mathrm{Dga}^{\mathrm{S}} \mathrm{TG}^{\mathrm{S}}$ ), and a subclone, CHO K1-T4, were

\footnotetext{
${ }^{3}$ Abbreviations used: Uridine diphosphate glucose (UDPG); uridine diphosphate galactose (UDP-Gal). Enzymes: galactokinase (EC 2.7.1.6); UDP-glucose: galactose-1-phosphate uridylyltransferase (EC 2.7.7.12); UDP-glucose 4'-epimerase (EC 5.1.3.2).
} 
used to isolate $\mathrm{Dga}^{\mathrm{R}} \mathrm{Pro}^{-} \mathrm{Gat}^{+} \mathrm{TG}^{\mathrm{s}}$ cells. $\mathrm{Gat}^{-} \mathrm{Pro}^{+} \mathrm{Dga}^{\mathrm{S}}$, referred to as $\mathrm{Gat}^{-}$, was kindly sent to us by Dr. Larry Thompson. Gat ${ }^{-}$, originally isolated from CHO-S by McBurney and Whitmore (6) and called AUX $\mathrm{B1}^{-}$, is auxotrophic for glycine, adenosine, and thymidine and lacks folylpolyglutamate synthetase (7). $\mathrm{Dga}^{\mathrm{R}} 27 \mathrm{TG}^{\mathrm{R}} \mathrm{Pro}^{+}$cells were derived from $\mathrm{Dga}^{\mathrm{R}} 27$ without mutagenesis after successively selecting for thioguanine resistance $\left(\mathrm{TG}^{\mathrm{R}}\right.$ ) in $60 \mu \mathrm{M}$ thioguanine (no HUT) and for $\mathrm{Pro}^{+}$in medium without proline at $10^{5}$ cells $/ 100-\mathrm{mm}$ petri dish.

Mutagenesis and Plating Efficiency. Cells growing exponentially in monolayer or suspension culture were treated with $N$-methyl- $N^{\prime}$-nitro- $N$ nitrosoguanidine (MNNG), $1 \mu \mathrm{g} / \mathrm{ml}$, for $5 \mathrm{~h}$ or with ethyl methanesulfonate (EMS), $100-400 \mu \mathrm{g} / \mathrm{ml}$ for $16 \mathrm{~h}$. After treatment, cells were washed, grown, and transferred when necessary in complete media for 6-11 days to allow for expression of the phenotype (reviewed in 8). Resistant cells were selected in complete media containing 30 or $60 \mathrm{mM}$ DGA after replating $10^{5}$ cells $/ 60 \mathrm{~mm}$ dish or $15 \mathrm{mM}$ DGA at $10^{4}$ cells/dish for $10-14$ days. Resistant cell lines $\mathrm{Dga}^{\mathrm{R}} 1$ to 26 were selected using 2deoxygalactose purchased from Sigma which contained traces of galactose. $\mathrm{Dga}^{\mathrm{R}} 27$ to 40 were isolated using the purer Aldrich DGA.

The relative plating efficiency in DGA expressed as a percent is 100 times the number of colonies or cells in deoxygalactose divided by the number of colonies or cells without deoxygalactose. Colonies were fixed with $12 \%$ formaldehyde and stained with $0.1 \%$ crystal violet.

Cell Hybridization. Dga ${ }^{\mathrm{R}} \mathrm{Gat}^{+} \mathrm{Pro}^{-}$cells, $5 \times 10^{5}$ cells $/ 35-\mathrm{mm}$ plate, were fused with $\mathrm{Dga}^{\mathrm{S}} \mathrm{Gat}^{-} \mathrm{Pro}^{+}$cells, $5 \times 10^{5}$ cells $/ 35-\mathrm{mm}$ plate, using $45 \%$ polyethylene glycol (9). 'As a control, two sensitive cell lines, $\mathrm{Dga}^{\mathrm{S}} \mathrm{Gat}^{-} \mathrm{Pro}^{+}$and CHO K1 $\left(\mathrm{Dga}^{\mathrm{S}} \mathrm{Gat}^{+} \mathrm{Pro}^{-}\right)$, were also fused. After 19-24 $\mathrm{h}$ in nonselective medium, fused cells were replated at $10^{3}$ and $10^{4}$ cells/60-mm dish in selective medium lacking proline, adenosine, and thymidine. Only hybrid clones (denoted as $\mathrm{K} 1 \times \mathrm{Gat}^{-}$or $\mathrm{Dga}^{\mathrm{R}}-\times \mathrm{Gat}^{-}$) which were $\mathrm{Gat}^{+} \mathrm{Pro}^{+}$could grow in the selective medium. $\mathrm{Dga}^{\mathrm{R}} 27 \mathrm{Pro}^{+} \mathrm{TG}^{\mathrm{R}}$ cells were fused with $\mathrm{Dga}^{\mathrm{R}} 24 \mathrm{Pro}^{-} \mathrm{TG}^{\mathrm{S}}$ or with $\mathrm{Dga}^{\mathrm{R}} 23 \mathrm{Pro}^{-} \mathrm{TG}^{\mathrm{S}}$, and the resulting hybrid cells $\left(\mathrm{TG}^{\mathrm{S}}\right.$ Pro ${ }^{+}$, denoted as $\mathrm{Dga}^{\mathrm{R}}-\times \mathrm{Dga}^{\mathrm{R}} 27$ ) were selected in HAT medium lacking proline. Resistance to thioguanine results from an X-linked recessive mutation yielding very low levels of hypoxanthine guanine phosphoribosyltransferase (10-14). $\mathrm{TG}^{\mathrm{R}}$ cells do not grow in HAT medium while $\mathrm{TG}^{\mathrm{R}} \times \mathrm{TG}^{\mathrm{S}}$ hybrid cells and $\mathrm{TG}^{\mathrm{S}}$ cells do $(13,14)$.

No revertants were observed among the unfused cell populations when $3 \times 10^{5}$ parental cells were plated in selective medium. Hybrid cell colonies were isolated, grown in selective medium, and five or more hybrid clones from each fusion combination were tested in medium with 
and without $6 \mathrm{mM}$ DGA at 200-500 cells/plate. The karyotype of each hybrid clone was determined by harvesting exponentially growing cells, washing with $0.56 \% \mathrm{KCl}$ and then with fixative solution (acetic acid/methanol, 1:3). Slides were prepared, stained with Giemsa, and 20 representative chromosome spreads were counted.

Enzyme Assays. Cell extracts for galactokinase assays were prepared at $4^{\circ} \mathrm{C}$ as follows. Cells, $30 \times 10^{6}$, were washed with $0.9 \% \mathrm{NaCl}$, resuspended in $0.5 \mathrm{ml}$ of buffer containing $0.01 \mathrm{M} \mathrm{KP}_{\mathrm{i}}, \mathrm{pH} 6.7 ; 1 \mathrm{mM}$ EDTA; $0.5 \mathrm{mM}$ dithiothreitol; sonicated at intervals for a total of $30 \mathrm{sec}$, and centrifuged at $17,400 \mathrm{~g}$ for $20 \mathrm{~min}$. The supernatant solution was passed through a column, $1 \times 3.8 \mathrm{~cm}$, of Sephadex G50 and eluted in the same buffer. After aliquots were taken for protein determination, the dithiothreitol concentration was adjusted to $2 \mathrm{mM}$. EDTA was omitted for ATP kinetic studies. For epimerase and transferase assays, the buffer was the same except the $\mathrm{pH}$ was 7.4 and extracts were assayed without Sephadex gel filtration. Protein was determined by the method of Lowry (15).

The procedure of Sherman and Adler (16) was modified to assay galactokinase. $\left[1-{ }^{14} \mathrm{C}\right]$ Galactose was incubated with ATP and hexokinase and passed over a column of DEAE 32 to remove any contaminating hexoses before use in the assay (17). In assay $\mathrm{A}$, which was used for kinetic studies, the reaction mixture contained $0.2 \mathrm{M}$ Tris- $\mathrm{Cl}, \mathrm{pH} 7.8,22^{\circ} \mathrm{C} ; 5 \mathrm{mM}$ $\mathrm{MgCl}_{2} ; 5 \mathrm{mM} \mathrm{NaF} ; 6 \mathrm{mM}$ ATP; $5 \mathrm{mM}$ dithiothreitol; [1-14 C]D-galactose (New England Nuclear), $0.54 \mu \mathrm{Ci} / \mathrm{ml} ; 0.4 \mathrm{mM}$ galactose. Assay B was the same except for the concentrations of $\mathrm{MgCl}_{2}, 2 \mathrm{mM}$; ATP, $2 \mathrm{mM}$; galactose, $0.2 \mathrm{mM}$; and $\left[1{ }^{14} \mathrm{C}\right]$ galactose, $1 \mu \mathrm{Ci} / \mathrm{ml}$. The reaction mixture was incubated for $30 \mathrm{~min}$ at $37^{\circ} \mathrm{C}$ and terminated by spotting three 25 - or $30-\mu \mathrm{l}$ aliquots on $1.5-\mathrm{cm}$ squares of DEAE paper (Whatman DE 81) and dropping immediately into $300 \mathrm{ml}$ of water. Papers were washed three times with water, dried, and counted in toluene containing $0.1 \mathrm{~g}$ POPOP and $5 \mathrm{~g}$ PPO per liter. The assay was linear with time and enzyme concentration at all galactose and ATP concentrations used.

UDPG epimerase was assayed at $37^{\circ} \mathrm{C}$ as described previously (17), except that $0.1 \mathrm{M}$ glycylglycine, $\mathrm{pH} 8.7$, and $1 \mathrm{mM}$ UDP-Gal were used. Galactose-1-phosphate uridylyltransferase was assayed at $37^{\circ} \mathrm{C}$ by a procedure similar to that of Mayes and Hansen (18). The reference and sample cuvettes contained $0.1 \mathrm{M}$ glycylglycine, $\mathrm{pH} 8.7 ; 1 \mathrm{mM} \mathrm{MgCl}_{2} ; 5$ $\mathrm{mM}$ dithiothreitol; $1 \mathrm{mM}$ NADP; $6 \mu \mathrm{M}$ glucose-1,6-diphosphate; $0.5 \mathrm{mM}$ UDPG; 0.1 units of phosphoglucomutase (Sigma); 0.1 units of glucose-6phosphate dehydrogenase (Type VII, Sigma); 0.005 units of 6-phosphogluconic acid dehydrogenase (Sigma); and extract in a final volume of 1 $\mathrm{ml}$. The reaction was intiated by adding galactose-1-phosphate, $0.65 \mathrm{mM}$, 
to the sample cuvette. The increase at $340 \mathrm{~nm}$ was followed. The blank reaction without extract was subtracted.

\section{RESULTS}

The frequency of colonies resistant to 2-deoxygalactose was increased by treatment with chemical mutagens (Table 1 ). The average spontaneous frequency of resistant colonies was $0.6 \times 10^{6}$, whereas the frequency induced by MNNG was $8.7 \times 10^{6}$. As the concentration of EMS was increased, the frequency of resistant colonies increased from 4 to $38 \times 10^{6}$. The resistant phenotype was stable after repeated cloning and continuous growth in medium without deoxygalactose for seven months. These results suggest that the resistant clones arose from gene mutation and not adaptation.

The concentration of DGA needed to inhibit growth of CHO K1 varied with the number of cells plated (Fig. 1). For example, $6 \mathrm{mM}$ DGA completely inhibited growth of CHO K1 when a low density of cells were plated ( $200-500$ cells $/ 60-\mathrm{mm}$ plate). However, the relative number of cells in DGA compared to media without DGA was $1 \%$ when $10^{5}$ cells were plated and $13 \%$ when $8 \times 10^{5}$ cells were plated in $6 \mathrm{mM}$ DGA. For this reason, plating experiments with sensitive and resistant cell lines in DGA were performed at low cell density.

When $\mathrm{CHO} \mathrm{K} 1$ was plated at 200 cells $/ 60-\mathrm{mm}$ dish in $6 \mathrm{mM}$ DGA, 2 $\mathrm{mM}$ galactose reversed the plating efficiency in DGA from $0 \%$ to $90 \%$ of that in media without the analog. $\mathrm{CHO} \mathrm{K} 1$ plated with an efficiency of only $5-7 \%$ in $6 \mathrm{mM}$ DGA when $55 \mathrm{mM}$ glucose, mannose, or fructose were added. Similarly, uridine, $0.12 \mathrm{mM}$, did not increase the plating efficiency in DGA.

Among 19 independently isolated clones, high and low levels of resistance to DGA were observed (Fig. 1). Most clones, such as $\mathrm{Dga}^{\mathrm{R}} 3$,

\begin{tabular}{cccc}
\hline \multicolumn{2}{c}{ Table 1. Induction of Mutants Resistant to 2-Deoxygalactose in CHO Cells } \\
\cline { 3 - 4 } \cline { 3 - 4 } Experiment & Mutagen & $\begin{array}{c}\text { Observed colonies/ } \\
\text { cells plated }\end{array}$ & $\begin{array}{c}\text { Mutation frequency } \\
\text { per 10 }\end{array}$ \\
\hline A & None & $5 / 6.4 \times 10^{6}$ & 1.04 \\
& MNNG $(1 \mu \mathrm{g} / \mathrm{ml})$ & $19 / 3.8 \times 10^{6}$ & 8.7 \\
& EMS $(400 \mu \mathrm{g} / \mathrm{ml})$ & $54 / 3.7 \times 10^{6}$ & 30.1 \\
B & None & $1 / 4 \times 10^{6}$ & 0.26 \\
& EMS $(100 \mu \mathrm{g} / \mathrm{ml})$ & $2 / 1 \times 10^{6}$ & 4.0 \\
& EMS $(200 \mu \mathrm{g} / \mathrm{ml})$ & $19 / 1 \times 10^{6}$ & 38.0 \\
& EMS $(400 \mu \mathrm{g} / \mathrm{ml})$ & $14 / 1 \times 10^{6}$ & 28.0 \\
\hline
\end{tabular}

${ }^{a}$ Corrected for plating efficiency without DGA. 


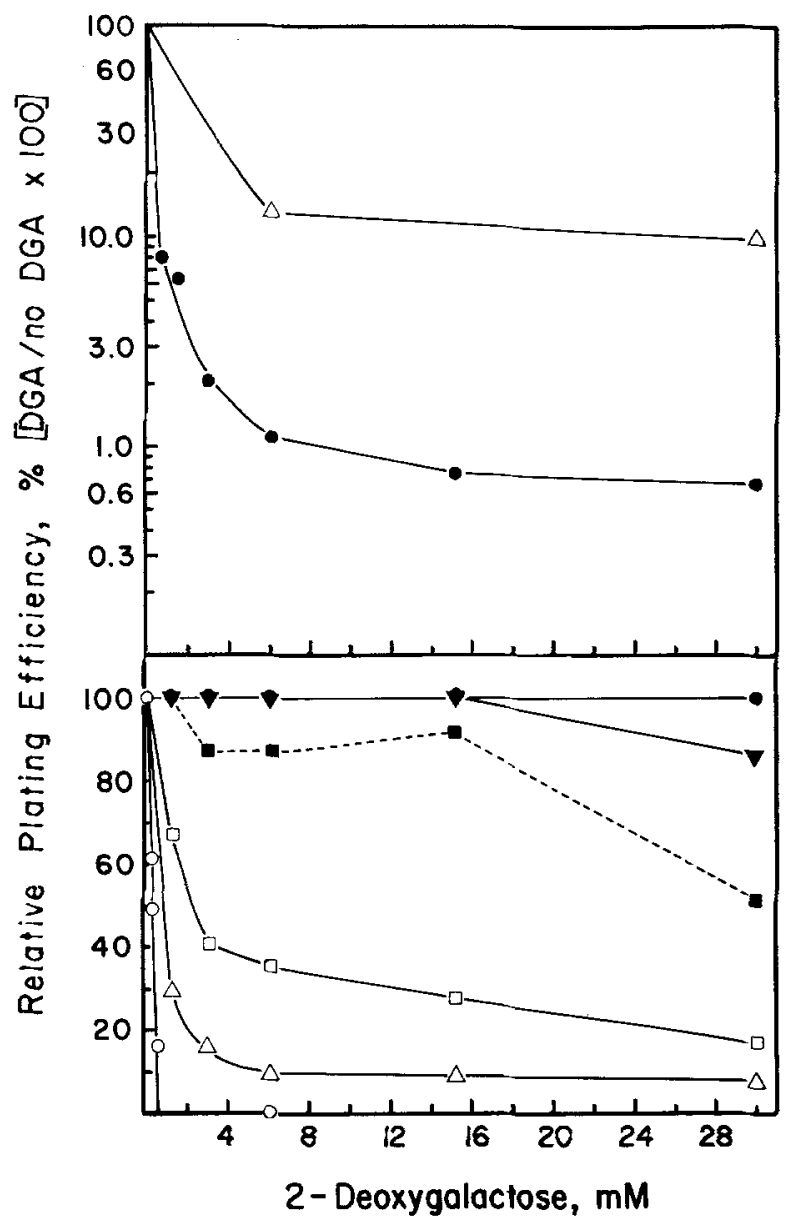

Fig. 1. Plating efficiency of sensitive and resistant cell lines in different concentrations of deoxygalactose. Upper panel (high cell density): CHO K1 was inoculated at $8 \times 10^{5}$ cells $/ 60$-mm plate, $\Delta$; and at $1 \times 10^{5}$ cells $/ 60-\mathrm{mm}$ plate, $\bullet$. In media without DGA, cells were removed with trypsin and counted at confluency (3-5 days); in media with DGA, cells were counted at 6-7 days. These numbers were used to calculate the relative plating efficiency. Lower panel (low cell density): cells were plated at $200-500$ cells $/ 60-\mathrm{mm}$ plate and colonies were stained and counted after 8-12 days. $\circ$, CHO Kl; $\Delta, \operatorname{Dga}^{\mathrm{R}} 26$;, $\mathrm{Dga}^{\mathrm{R}} 24 ;-\mathrm{Dga}^{\mathrm{R}} 6$; $\nabla, \operatorname{Dga}^{\mathrm{R}} 3 ; \bullet, \mathrm{Dga}^{\mathrm{R}} 8$.

6,27 , were highly resistant to DGA and did not grow on galactose as a sole carbon source (Table 2). The plating efficiency of these clones in 6 mM DGA was $87-100 \%$ of that without DGA compared to $0 \%$ for $\mathrm{CHO}$ $\mathrm{K} 1$. Three clones, $\mathrm{Dga}^{\mathrm{R}} 23,24,26$, were isolated which had low resistance to DGA and grew on galactose. $\mathrm{Dga}^{\mathrm{R}} 23,24,26$ plated in $6 \mathrm{mM}$ DGA with an efficiency of $10-30 \%$ even after successive recloning. 
Table 2. Properties of Deoxygalactose-Sensitive and-Resistant CHO Cells

\begin{tabular}{|c|c|c|c|c|c|c|}
\hline \multirow[b]{2}{*}{ Cell line } & \multirow[b]{2}{*}{ Mutagen } & \multirow{2}{*}{$\begin{array}{l}\text { Relative } \\
\text { plating } \\
\text { Efficiency }(\%)\end{array}$} & \multirow{2}{*}{$\begin{array}{l}\text { Growth in } \\
\text { galactose }^{b}\end{array}$} & \multicolumn{3}{|c|}{ Specific activity } \\
\hline & & & & Kinase & Epimerase & Transferase \\
\hline $\mathrm{CHO} \mathrm{Kl}$ & none & $<0.13$ & + & 4.17 & 7.14 & 3.14 \\
\hline $\mathrm{CHO} \mathrm{Kl}-\mathrm{T} 4$ & none & $<0.08$ & + & 4.47 & 7.33 & 4.33 \\
\hline DG 3-1 & MNNG & 100 & - & 0 & 6.90 & 3.29 \\
\hline DG 6-1 & MNNG & 87 & - & 0 & 7.16 & 2.44 \\
\hline DG 8-1 & MNNG & 100 & - & 0.02 & 7.58 & 1.62 \\
\hline DG 23-1-1 & EMS & 14 & + & 1.07 & 6.80 & 3.04 \\
\hline DG 24-4-3 & EMS & 30 & + & 1.40 & 6.80 & 3.18 \\
\hline DG 26-1 & EMS & 10 & + & 0.32 & 6.95 & 3.44 \\
\hline DG 27-1 & none & 97 & - & 0 & 6.35 & 3.75 \\
\hline DG $30-1$ & EMS & 89 & - & 0 & 7.33 & 3.79 \\
\hline DG 31-1 & MNNG & 91 & - & 0 & 8.61 & 4.07 \\
\hline DG 32-1 & EMS & 100 & - & 0 & 10.59 & 4.69 \\
\hline \multicolumn{7}{|c|}{$\begin{array}{l}\text { a Plating in }(6 \mathrm{mM} \text { DGA } / 0 \mathrm{mM} \text { DGA }) \times 100 ; 200-500 \text { cells } / 60-\mathrm{mm} \text { dish; } 3-4 \text { plates each DGA } \\
\text { concentration. } \\
{ }^{b} 1 \times 10^{5} \text { cells } / 60-\mathrm{mm} \text { plate in } 15 \mathrm{mM} \text { galactose. } \\
\text { c Specific activity in nmol } / \mathrm{min} / \mathrm{mg} \text { protein. Galactokinase was determined with as }\end{array}$} \\
\hline
\end{tabular}

Galactokinase specific activity is reduced in all deoxygalactoseresistant cell lines (Table 2). The highly resistant cells had less than $1 \%$ of the activity observed in $\mathrm{CHO} \mathrm{K} 1$. Cell lines with low resistance had $7-31 \%$ of the galactokinase activity present in the sensitive parental cells. When sensitive and resistant cell extracts were mixed, the galactokinase activity of the sensitive cells was not inhibited. Removal of small molecules by Sephadex G-50 gel filtration did not restore activity in resistant cell extracts. Thus the lack of galactokinase activity in the resistant cells was not due to the presence of an inhibitor. UDPG epimerase activity in resistant cell lines is nearly the same or slighly higher than in sensitive cells. Galactose-1-P uridylyltransferase activity is also not significantly different in $\mathrm{Dga}^{\mathrm{R}}$ cells from that of sensitive cells. $\mathrm{Dga}^{\mathrm{R}} 6$ and $\mathrm{Dga}^{\mathrm{R}} 8$ have somewhat reduced levels of transferase activity which may be due to clonal variation.

In order to determine if the galactokinase protein is altered in cells with low resistance, the kinetic and thermosensitivity properties of the enzyme were examined in cell free extracts after Sephadex G-50 gel filtration. $\mathrm{Dga}^{\mathrm{R}} 24, \mathrm{Dga}^{\mathrm{R}} 26$, and CHO K1 showed the same loss of enzyme activity when heat inactivated at $44-51^{\circ} \mathrm{C}$ for up to $10 \mathrm{~min}$ and then assayed at $37^{\circ} \mathrm{C}$.

The $K_{m}$ for galactose and ATP, $K_{i}$ for deoxygalactose, and $V_{\max }$ per $\mathrm{mg}$ of protein were determined from Lineweaver-Burk plots where the galactose concentration was varied in the presence of a constant amount of the inhibitor analog DGA (Fig. 2). Three of the 4 lines intersect at a 


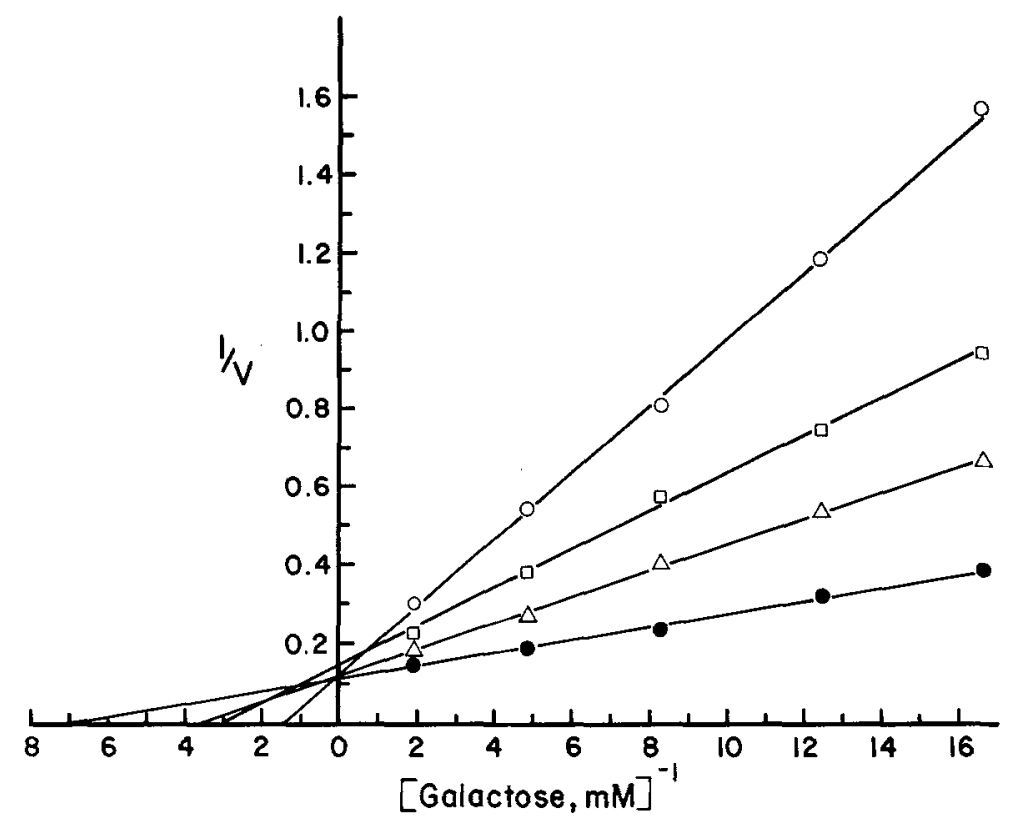

Fig. 2. Lineweaver-Burk plot of galactokinase activity in $\mathrm{CHO} \mathrm{K} 1$ cells. The concentration of galactose was varied in the presence of a constant concentration of deoxygalactose (Aldrich). $\bullet, 0 \mathrm{mM}$ DGA; $\triangle, 5 \mathrm{mM}$ DGA;, $10 \mathrm{mM}$ DGA; $\circ, 20 \mathrm{mM}$ DGA. Lines were drawn from regression analysis.

single point on the $y$ axis as expected for a pure competitive inhibitor of galactose. The small deviation in the fourth line is within the variation of the radioactive assay. The $K_{m}$ and $V_{m a x}$ were calculated from the $x$ and $y$ intercepts, respectively. The $K_{i}$ for deoxygalactose was calculated from the $x$ intercept in a secondary plot of the slopes from the LineweaverBurk plot versus the inhibitor concentration (19) (Fig. 3). Similar data were obtained for $\operatorname{Dga}^{k} 23,24$, and 26 and are summarized in Table 3. The $V_{\max }$ per mg of protein is $24 \%$ of the average value for $\mathrm{CHO} \mathrm{K} 1$ and T4 with $\mathrm{Dga}^{\mathrm{R}} 23 ; 31 \%$ with $\mathrm{Dga}^{\mathrm{R}} 24 ; 7 \%$ with $\mathrm{Dga}^{\mathrm{R}} 26$. However, the $K_{w_{3}}$ for galactose, $K_{i}$ for deoxygalactose, and $K_{x ;}$ for ATP were not significantly altered in the resistant cells compared to the sensitive cells.

Deoxygalactose resistant cells were fused with sensitive cells to determine if resistance is a recessive or dominant trait. If resistance is recessive, these tetraploid hybrid cells are expected to be sensitive to DGA. As a control, two sensitive cell lines, $\mathrm{K} 1$ and $\mathrm{Gat}^{-}$, were also fused. Most $\mathrm{K} 1 \times \mathrm{Gat}^{-}$clones showed a plating efficiency in $6 \mathrm{mM}$ DGA from 0 to $5 \%$ of that with no DGA; one unusual hybrid $\mathrm{K} 1 \times \mathrm{Gat}^{-}$clone 12 exhibited an even higher plating of $18.6 \%$ (Table 4 ). Hybrid clones formed from sensitive cells and cells with low resistance, $\mathrm{Dga}^{\mathrm{R}} 24 \times \mathrm{Gat}^{-}$and 


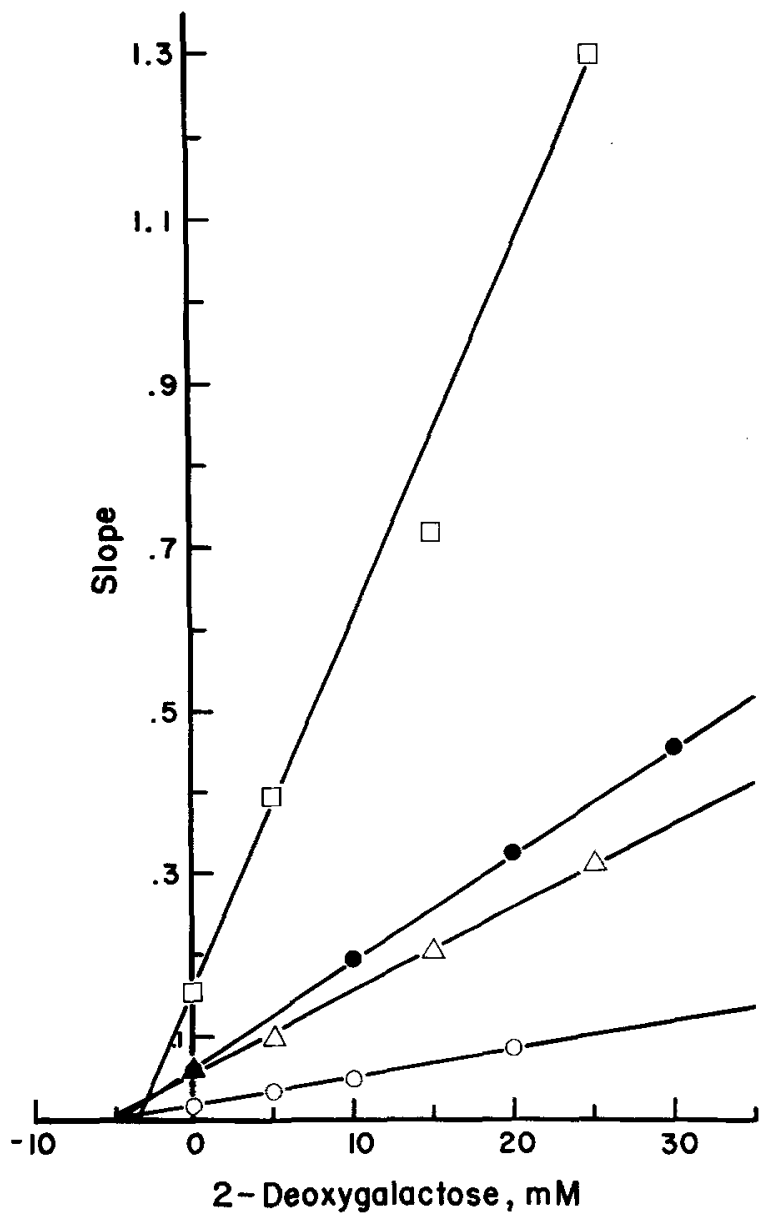

Fig. 3. Secondary plot of the data from Fig. 2 and other data not shown. DGA concentration is plotted versus the slope of the Lineweaver-Burk curves where galactose concentration was varied in the presence of a constant concentration of DGA. $0, \mathrm{CHO} \mathrm{K1;} \triangle, \mathrm{Dga}^{R} 23-1-1$; -, $\operatorname{Dga}^{\mathrm{R}} 24-4-3$; 口, $\mathrm{Dga}^{\mathrm{R}}$ 26-1.

Dga $^{\mathrm{R}} 23 \times \mathrm{Gat}^{-}$, plated with an efficiency of $0-10 \%$ in $6 \mathrm{mM}$ DGA. With one exception hybrid clones formed between highly resistant cells and sensitive cells, $\mathrm{Dga}^{\mathrm{R}} 27 \times \mathrm{Gat}^{-}$, exhibited a plating efficiency of $3-20 \%$ in $6 \mathrm{mM}$ DGA. On the basis of colony size and plating efficiency in different concentrations of DGA (Fig. 4), hybrids $\mathrm{Dga}^{\mathrm{R}} 23 \times \mathrm{Gat}^{-}, \mathrm{Dga}^{\mathrm{R}}$ $24 \times \mathrm{Gat}^{-}$, and $\mathrm{Dga}^{\mathrm{R}} 27 \times \mathrm{Gat}^{-}$were more similar to the sensitive control hybrid, $\mathrm{K} 1 \times \mathrm{Gat}^{-}$, than to their resistant diploid parental cells. Therefore we conclude that DGA resistance is a recessive trait.

The higher plating efficiency of $\mathrm{Dga}^{\mathrm{R}} 23 \times \mathrm{Gat}^{-}, \mathrm{Dga}^{\mathrm{R}} 24 \times \mathrm{Gat}^{-}$, 
Table 3. Kinetic Properties of 2-Deoxygalactose-Sensitive and-Resistant CHO Cells

\begin{tabular}{lcccc}
\hline Cell line & $\begin{array}{c}V_{\text {max }} / \text { protein }^{a} \\
(\mathrm{nmoles} / \mathrm{min} / \mathrm{mg})\end{array}$ & $\begin{array}{c}\text { Galactose } K_{m} \\
(\mathrm{mM})\end{array}$ & $\begin{array}{c}\text { Deoxygalactose } K_{i} \\
(\mathrm{mM})\end{array}$ & $\begin{array}{c}\text { ATP } K_{m} \\
(\mathrm{mM})\end{array}$ \\
\hline CHO Kl & 5.66 & 0.147 & 4.49 & 0.084 \\
CHO K1-T4 & 6.43 & 0.180 & 5.08 & N.D ${ }^{b}$ \\
DG 23-1-1 & 1.44 & 0.143 & 5.28 & N.D. \\
DG 24-4-3 & 1.86 & 0.134 & 4.73 & 0.094 \\
DG 26-1 & 0.42 & 0.126 & 3.52 & 0.067 \\
\hline
\end{tabular}

${ }^{a}$ Assay A was used for the kinetic studies. $V_{\max }$ was determined from varying galactose concentrations.

${ }^{b}$ N.D. = not determined.

$\mathrm{Dga}^{\mathrm{R}} 27 \times \mathrm{Gat}^{-}$, and $\mathrm{K} 1 \times \mathrm{Gat}^{-}$clone 12 in DGA compared to the sensitive control $\mathrm{K} 1 \times \mathrm{Gat}^{-}$clone 1 (Fig. 4) is a reflection of lower galactokinase activity in these hybrids relative to $\mathrm{K} 1 \times \mathrm{Gat}^{-}$clone 1 (Table 4). Galactokinase specific activity of hybrids formed between $\mathrm{Dga}^{\mathrm{R}}$ and $\mathrm{Gat}^{-}$ cells and $\mathrm{K} 1 \times \mathrm{Gat}^{-}$clone 12 was $48-62 \%$ of that observed with $\mathrm{K} 1 \times \mathrm{Gat}^{-}$clones 1 and 18 . With the exception of $\mathrm{K} 1 \times \mathrm{Gat}^{-}$clone 12 and $\mathrm{Dga}^{\mathrm{R}} 27 \times \mathrm{Gat}^{-}$clone 4 , this was the level of galactokinase activity

\begin{tabular}{|c|c|c|c|c|c|}
\hline \multirow[b]{2}{*}{ Cell line } & \multicolumn{2}{|c|}{$\begin{array}{l}\text { Chromosome } \\
\text { number }\end{array}$} & \multirow{2}{*}{$\begin{array}{c}\text { Relative } \\
\text { plating } \\
\text { efficiency }^{a}(\%)\end{array}$} & \multicolumn{2}{|c|}{ Galactokinase $^{b}$} \\
\hline & Mean & $\sigma$ & & Spec. act. & $\%$ \\
\hline $\mathrm{Gat}^{-}$ & 21.0 & 0.9 & $<0.05$ & 3.9 & \\
\hline $\mathrm{K} 1 \times \mathrm{Gat}^{-}-1$ & 38.2 & 1.3 & $<0.13$ & 3.53 & 100 \\
\hline $\mathrm{K} 1 \times \mathrm{Gat}^{-}-18$ & 38.6 & 2.8 & 2.0 & 3.23 & 100 \\
\hline $\mathrm{Kl} \times \mathrm{Gat}^{-}-12$ & 37.4 & 1.6 & 18.6 & 1.89 & 56 \\
\hline $\mathrm{Dga}^{\mathrm{R}} 27 \times \mathrm{Gat}^{-}-1$ & 41.3 & 4.1 & 20.3 & 1.62 & 48 \\
\hline $\mathrm{Dga}^{\mathrm{R}} 27 \times \mathrm{Gat}^{-}-3$ & 40.3 & 1.5 & 8.7 & 1.73 & 51 \\
\hline $\mathrm{Dga}^{\mathrm{R}} 27 \times \mathrm{Gat}^{-}-4$ & 38.9 & 1.9 & 66.7 & 0.19 & 6 \\
\hline $\mathrm{Dga}^{\mathrm{R}} 27 \times \mathrm{Gat}^{-}-5$ & 34.3 & 2.6 & 3.3 & 1.92 & 57 \\
\hline $\operatorname{Dga}^{\mathrm{R}} 24 \times \mathrm{Gat}^{-}-6$ & 39.6 & 1.9 & 5.9 & 1.98 & 59 \\
\hline $\mathrm{Dga}^{\mathrm{R}} 24 \times \mathrm{Gat}^{-}-11$ & 38.0 & 1.7 & 6.5 & 1.92 & 57 \\
\hline $\mathrm{Dga}^{\mathrm{K}} 23 \times \mathrm{Gat}^{-}-7$ & 39.9 & 3.1 & 0.6 & 2.10 & 62 \\
\hline $\mathrm{Dga}^{\mathrm{R}} 23 \times \mathrm{Gat}^{-}-11$ & 40.9 & 2.1 & 3.1 & 2.09 & 62 \\
\hline $\operatorname{Dga}^{\mathrm{R}} 24 \times \operatorname{Dga}^{\mathrm{R}} 27-6$ & 39.2 & 2.9 & 67.0 & 0.72 & 21 \\
\hline $\mathrm{Dga}^{\mathrm{R}} 24 \times \mathrm{Dga}^{\mathrm{R}} 27-8$ & 40.7 & 2.9 & 61.3 & 0.47 & 14 \\
\hline $\operatorname{Dga}^{\mathrm{R}} 23 \times \operatorname{Dga}^{\mathrm{R}} 27-18$ & 38.3 & 1.6 & 61.7 & 0.60 & 18 \\
\hline $\mathrm{Dga}^{\mathrm{R}} 23 \times \mathrm{Dga}^{\mathrm{R}} 27-20$ & 40.7 & 2.0 & 54.2 & 0.65 & 19 \\
\hline \multicolumn{6}{|c|}{$\begin{array}{l}{ }^{a} \text { Plating in }(6 \mathrm{mM} \text { DGA } / 0 \mathrm{mM} \text { DGA }) \times 100 ; 200-500 \text { cells } / 60-\mathrm{mm} \text { dish; } 3-4 \text { plates each DGA } \\
\text { concentration. }\end{array}$} \\
\hline
\end{tabular}






Fig. 4. Plating of representative diploid and tetraploid clones in DGA at 200-500 cells/60mm dish, 4 plates each DGA concentration. Panel A: $\square, \mathrm{Dga}^{\mathrm{R}}$ 27-1 $\mathrm{TG}^{R} \mathrm{Pro}^{+} ; \nabla, \mathrm{Dga}^{\mathrm{R}} 23-1-$ $1 \times \mathrm{Dga}^{\mathrm{R}} 27-1$ clone $20 ; \mathbf{\mathrm { M }}, \mathrm{Dga}^{\mathrm{R}} 27-1 \times \mathrm{Gat}^{-}$clone $1 ; \boldsymbol{\Delta}, \operatorname{Dga}^{\mathrm{R}} 23-1-1 ; \Delta, \mathrm{Dga}^{\mathrm{R}} 23-1-$ $1 \times \mathrm{Gat}^{-}$clone $11 ; 0, \mathrm{~K} 1 ; \bullet, \mathrm{K} 1 \times \mathrm{Gat}^{-}$clone 1 . Panel B: $\circ, \mathrm{Dga}^{\mathrm{R}} 27-1 ; \nabla, \mathrm{Dga}^{\mathrm{R}} 24-4-$ $3 \times \mathrm{Dga}^{\mathrm{R}} 27-1$ clone 8; $\boldsymbol{\Lambda}, \mathrm{Dga}^{\mathrm{R}} 24-4-3 ; \mathrm{D}, \mathrm{K} 1 \times \mathrm{Gat}^{-}$clone $12 ; \bullet, \mathrm{Dga}^{\mathrm{R}} 27-1 \times \mathrm{Gat}^{-}$clone 1; $\triangle$, Dga $^{\mathrm{R}} 24-4-3 \times \mathrm{Gat}^{-}$clone $11 ; \mathbf{m}, \mathrm{Gat}^{-}$.

expected for coexpression of enzyme activity considering the activity in the diploid parental cells.

Two atypical clones, $\mathrm{Dga}^{\mathrm{R}} 27 \times \mathrm{Gat}^{-}$clone 4 and $\mathrm{K} 1 \times \mathrm{Gat}^{-}$clone 12 clearly have a much higher plating efficiency in DGA than other clones from these crosses. In both cases, the higher plating corresponded with decreased galactokinase activity. It is possible that these particular hybrids have lost a functional wild-type (structural or regulatory) gene for galactokinase soon after cell fusion since the selected markers were $\mathrm{Gat}^{+} \mathrm{Pro}^{+}$. Chromosomal loss, rearrangement, and alteration is increased in tetraploid CHO cells (20). Since the frequency of their occurrence is high $(8-20 \%)$, it is unlikely that these unusual clones arose by mutation. If the galactokinase gene is functionally hemizygous (see Discussion) in DGA-sensitive CHO cells and one wild-type allele is lost or inactivated in the tetraploid cell, one would expect $\mathrm{K} 1 \times \mathrm{Gat}^{-}$clone 12 to have about $50 \%$ of the enzyme activity observed in $\mathrm{K} 1 \times \mathrm{Gat}^{-}$clone 1 and $\mathrm{Dga}^{\mathrm{R}}$ $27 \times \mathrm{Gat}^{-}$clone 4 , about $0 \%$. The observed values of $56 \%$ and $6 \%$, respectively, are in good agrement with the predicted ones.

The second series of hybridization experiments involved fusion between cells with high DGA resistance and those with low resistance to 
determine if they complemented each other. If complementation occurs, hybrid cells, $\mathrm{Dga}^{\mathrm{R}} 23 \times \mathrm{Dga}^{\mathrm{R}} 27$ or $\mathrm{Dga}^{\mathrm{R}} 24 \times \mathrm{Dga}^{\mathrm{R}} 27$, would be sensitive to DGA and plating in DGA would be intermediate between that of hybrids formed from the respective resistant cells and sensitive cells $\left(\mathrm{Dga}^{\mathrm{R}} 23 \times \mathrm{Gat}^{-}\right.$and $\mathrm{Dga}^{\mathrm{R}} 27 \times \mathrm{Gat}^{-}$or $\mathrm{Dga}^{\mathrm{R}} 24 \times \mathrm{Gat}^{-}$and $\mathrm{Dga}^{\mathrm{R}} 27 \times \mathrm{Gat}^{-}$). On the other hand, if complementation does not take place, hybrid cells, $\mathrm{Dga}^{\mathrm{R}} 23 \times \mathrm{Dga}^{\mathrm{R}} 27$ or $\mathrm{Dga}^{\mathrm{R}} 24 \times \mathrm{Dga}^{\mathrm{R}} 27$, would be resistant to DGA and plating in DGA would be intermediate between that of the respective resistant parents $\left(\mathrm{Dga}^{\mathrm{R}} 23\right.$ and $\mathrm{Dga}^{\mathrm{R}} 27$ or $\mathrm{Dga}^{\mathrm{R}} 24$ and $\left.\mathrm{Dga}^{\mathrm{R}} 27\right) . \quad \mathrm{Dga}^{\mathrm{R}} 23 \times \mathrm{Dga}^{\mathrm{R}} 27$ and $\mathrm{Dga}^{\mathrm{R}} 24 \times \mathrm{Dga}^{\mathrm{R}} 27$ gave large colonies in medium containing DGA with a high plating efficiency of 50 $80 \%$ (Table 4). Plating of these hybrids at different concentrations of DGA was intermediate between that of the respective resistant parental cells (Fig. 4). Galactokinase activity in $\operatorname{Dga}^{\mathrm{R}} 23 \times \mathrm{Dga}^{\mathrm{R}} 27$ and $\mathrm{Dga}^{\mathrm{R}} 24 \times \mathrm{Dga}^{\mathrm{R}}$ 27 was $14-21 \%$ of that observed in the sensitive control hybrids, $\mathrm{K} 1 \times \mathrm{Gat}^{-}$clones 1 and 18 (Table 4). From the high plating efficiency in DGA and the low galactokinase activity in $\operatorname{Dga}^{\mathrm{R}} 23 \times \mathrm{Dga}^{\mathrm{R}} 27$ and $\mathrm{Dga}^{\mathrm{R}}$ $24 \times \operatorname{Dga}^{R} 27$, we conclude that cells with high resistance did not complement those with low resistance with respect to DGA resistance of in vitro galactokinase activity.

\section{DISCUSSION}

The increased number of resistant cells after treatment with chemical mutagens and the stability in the absence of selection suggest that DGA resistance arises from gene mutation. Although $\mathrm{CHO}$ cells in culture are diploid in terms of DNA content, extensive chromosomal rearrangement has occurred compared to the Chinese hamster (20). Since so many autosomal recessive mutants have been isolated in $\mathrm{CHO}$, Siminovitch (21) has suggested that $\mathrm{CHO}$ may be functionally hemizygous for many autosomal gene loci due to chromosomal rearrangement. This may be the case with DGA resistance. Considering that resistance is recessive, the spontaneous frequency, $0.6 \times 10^{6}$, is consistent with a functionally hemizygous state in $\mathrm{CHO}$ due to $\mathrm{X}$ linkage or autosomal rearrangement (22). The galactokinase structural gene has been mapped on autosomal chromosomes in humans (23), primates (24), and mice (25).

Galactokinase activity is reduced in all DGA-resistant cell lines derived from $\mathrm{CHO} \mathrm{K} 1$. Thus, formation of deoxygalactose-1-phosphate is implicated in growth inhibition by DGA. In rat ascites hepatoma cells, DGA-1-P represents $99 \%$ of the total metabolites of DGA (26). In rat liver, UDP-deoxyhexoses are also formed from DGA (27). These studies suggest that DGA might inhibit growth by depletion of the intracellular pools 
of inorganic phosphate or uridine. If DGA inhibits cell growth by trapping uridine, then uridine or other hexoses, such as glucose, fructose, or mannose, which are metabolized to UDPG and UDPGal might reverse the inhibition. We found that galactose but not glucose, fructose, mannose, or uridine reversed the DGA inhibition of growth of $\mathrm{CHO}$ cells. Therefore, it is likely that DGA primarily inhibits growth because it accumulates as DGA-1-P in a reaction catalyzed by galactokinase. This results in the trapping of inorganic phosphate which is required for energy production by glycolysis and oxidative phosphorylation. There are several possible reasons why all of our resistant cell lines are defective in galactokinase activity and none deficient at other steps: (1) DGA is not metabolized further than DGA-1-P; (2) a double mutation is required to significantly affect activity at other loci; (3) we have examined too few resistant cell lines, or (4) our selective conditions are not optimal to detect other types of mutations.

Most interestingly, there is a rough inverse relationship between the level of galactokinase activity and the plating efficiency in DGA. With one exception $\left(\mathrm{Dga}^{\mathrm{R}} 26\right)$, sensitive and resistant cell lines fall into four groups. The first group is represented by sensitive cell lines as $\mathrm{CHO} \mathrm{K1}, \mathrm{T} 4$, $\mathrm{Gat}^{-}$, $\mathrm{K} 1 \times$ Gat clones 1 and 18 , which plate with an efficiency of $0-3 \%$ in DGA and have 65-100\% galactokinase activity. The second group (e.g., $\mathrm{Dga}^{\mathrm{R}} 23 \times \mathrm{Gat}^{-}, \mathrm{Dga}^{\mathrm{R}} 24 \times \mathrm{Gat}^{-}, \mathrm{Dga}^{\mathrm{R}} 27 \times \mathrm{Gat}^{-}, \mathrm{K} 1 \times \mathrm{Gat}^{-}$clone 12 ) is very slightly resistant with a plating efficiency of $1-20 \%$ in DGA and enzyme activity of $48-62 \%$. The third group is composed of cells with low resistance, as $\mathrm{Dga}^{\mathrm{R}} 23$ and $\mathrm{Dga}^{\mathrm{R}} 24$, which have a plating efficiency of 14$30 \%$ in DGA and $24-31 \%$ galactokinase activity. The last group (e.g., $\mathrm{Dga}^{\mathrm{R}} 27, \quad \mathrm{Dga}^{\mathrm{R}} 23 \times \operatorname{Dga}^{\mathrm{R}} 27, \quad \operatorname{Dga}^{\mathrm{R}} 24 \times \mathrm{Dga}^{\mathrm{R}} 27, \quad \mathrm{Dga}^{\mathrm{R}} 27 \times \mathrm{Gat}^{-}$ clone 4) is highly resistant with $54-100 \%$ plating in DGA and $0-21 \%$ enzyme activity. It is noteworthy that two atypical hybrid clones, $\mathrm{K} 1 \times \mathrm{Gat}^{-}$clone 12 and $\mathrm{Dga}^{\mathrm{R}} 27 \times \mathrm{Gat}^{-}$clone 4 , picked at random for traits other than resistance, exhibited a higher plating efficiency in DGA than other clones from these crosses and simultaneously showed a decreased galactokinase activity. This further confirms the inverse relationship between DGA resistance and the level of galactokinase activity.

Analysis of DGA resistance and in vitro galactokinase activity in $\mathrm{Dga}^{\mathrm{R}} \times \mathrm{Dga}^{\mathrm{S}}$ hybrid cells show that resistance is a recessive mutation and that galactokinase levels are those expected for coexpression of the enzyme activity. Cells with high resistance do not complement those with low resistance with respect to plating in DGA or galactokinase activity in extracts. The lack of complementation indicates that cell lines with high and low resistance have mutations in the same cistron affecting galactokinase activity. Since galactokinase is a simple monomeric protein (28), dif- 
ferent mutations in the structural gene for this enzyme clearly would not complement one another. However, mutation at a regulatory locus affecting transcription or translation of galactokinase is also possible.

The reduced activity of galactokinase in the $\mathrm{Dga}^{\mathrm{R}}$ cells could be due to a mutation in a regulatory gene or structural gene. A regulatory mutation affecting transcription, posttranscription, or translation will not modify the thermolability or kinetic properties of the galactokinase enzyme in the resistant cells compared to the sensitive parental cells. These properties might be altered in a structural gene mutation (11) or mutation affecting posttranslational modification of the protein. Although the $V_{\text {max }}$ per mg of protein was reduced in cells with low resistance, the $K_{m}$ for galactose, $K_{i}$ for deoxygalactose, $K_{m}$ for ATP, and thermolability were not significantly altered. Hence, it is possible that the reduced enzyme activity is due to a regulatory gene mutation which decreases the number of protein molecules per cell. However, a structural gene mutation which decreased the activity of the protein is not completely ruled out.

\section{ACKNOWLEDGMENTS}

We greatly appreciate the many helpful discussions with Drs. Dennis Yep and Harvey Whitfield. We would like to thank Drs. Miriam Meisler and Elaine Lewis for reading the manuscript. This research was supported by grants GM-20608 and AM-19602 from the U.S. Public Health Service. This work was done in part during the tenure of an Established Investigatorship from the American Heart Association awarded to C.W.

\section{LITERATURE CITED}

1. Alper, M. D., and Ames, B. N. (1975). J. Bacteriol. 121:259-266.

2. Nagelkerke, F., and Postma, P. W. (1978). J. Bacteriol. 133:607-613.

3. Thirion, J.-P., Banville, D., and Noel, H. (1976). Genetics 83:137-147.

4. Whitfield, C. D., and Chu, E. H. Y. (1976). Experta Med. Int. Congr. Ser. 397:55.

5. Eagle, H. (1959). Science 130:432-437.

6. McBurney, M. W., and Whitmore, G. F. (1976). Cell 2:173-182.

7. Taylor, R. T., and Hanna, M. L. (1977). Arch. Biochem. Biophys, 181:331-344.

8. Chu, E. H. Y., and Powell, S. S. (1976). In Adv. Hum. Genet, Vol. 7 (ed. by Harris, H., and Hirschhorn, K.) (Plenum Press, New York), pp. 189-258.

9. Davidson, R. L., O'Malley, K. A., and Wheeler, T. B. (1976) Somat. Cell Genet. 2:271-280.

10. Stutts, P., and Brockman, R. W. (1963), Biochem. Pharmacol. 12:97-104.

11. Sharp, J. D., Capecchi, N. E., and Capecchi, M. R. (1973). Proc. Natl. Acad. Sci. U.S.A. 70:3145-3149.

12. Farrell, S. A., and Worton, R. G. (1977). Somat. Cell Genet. 3:539-551.

13. Littlefield, J. W. (1964). Science 145:709.

14. Chu, E. H. Y., Brimer, P., Jacobson, K. B., and Merriam, E. V. (1969). Genetics 62:359-377. 
15. Lowry, O. H., Rosebrough, N. J., Farr, A. L., and Randall, R. J. (1951). J. Biol. Chem. 193:265-275.

16. Sherman, J. R., and Adler, J. (1963). J. Biol. Chem. 238:873-878.

17. Beutler, E. (1975). Red Cell Metabolish, 2nd ed. (Grune \& Stratton, New York), pp. $97-102$.

18. Mayes, J. S. and Hansen, R. G. (1966). In Methods in Enzymology, Vol. 9 (ed. by Wood, W. A.) (Academic Press, New York), pp. 708-713.

19. Segel, I. H. (1975). Enzyme Kinetics (J. Wiley, New York), pp. 108-109.

20. Worton, R. G., Ho, C. C., and Duff, C. (1977). Somat. Cell Genet. 3:27-45.

21. Siminovitch, L. (1976). Cell 7:1-11.

22. Chasin, L. A. (1973). J. Cell Physiol. 82:299-308.

23. Elsevier, S. M., Kucherlapati, R. S., Nichols, E. A., Creagan, R. P., Giles, R. E., Ruddle, F. H., Willecke, K., and McDougall, J. K. (1974). Nature 251:633-635.

24. Orkwiszewski, K. G., Tedesco, T. A., Mellman, W. J., and Croce, C. M. (1976). Somat. Cell Genet. 2:21-26.

25. Kozak, C. A., and Ruddle, F. H. (1977). Somat. Cell Genet. 3:121-133.

26. Smith, D. F., and Keppler, D. O. R. (1977). Eur. J. Biochem. 73:83-92.

27. Starling, J. J., and Keppler, D. O. R. (1977). Eur. J. Biochem. 80:373-379.

28. Wilson, D. B., and Hogness, D. S. (1966). In Methods in Enzymology, Vol. 8 (eds.) Neufeld, E. F., and Ginsburg, V. (Academic Press, New York), pp. 229-240. 